\title{
Does metro proximity promote happiness? Evidence from Shanghai
}

\author{
Wan Li \\ East China Normal University \\ Iw1436@163.com
}

\section{Chun Yin}

East China Normal University

innocent1214@163.com

\section{Qianqian Liu}

Chinese Academy of Sciences

liuqq.15b@igsnrr.ac.cn

\author{
Bindong Sun (Corresponding Author) \\ East China Normal University \\ bdsun@re.ecnu.edu.cn
}

\author{
Tinglin Zhang \\ East China Normal University \\ ztlbjy@126.com
}

\begin{abstract}
Although an increasing number of scholars are evaluating rail transit benefits, there have been surprisingly few studies of the links between metro proximity and happiness. The principal objective of this paper is to assess the benefits of metro proximity for individual's happiness. A key challenge to empirically answering this question is the fact that residential location is likely to be the result of self-selection, i.e., personal preference, such that living around a rail station can increase residents' happiness. Taking advantage of the largely exogenous residential locations of those who bought their house 10 years earlier than the operation of their nearest metro station and those households living in non-market housing in Shanghai, we find proximity to a subway station robustly promotes happiness at the individual level. These results suggest that the development of rail transit and transit-oriented development (TOD) are promising ways to increase happiness.
\end{abstract}

Keywords: metro proximity, happiness, self-selection, Shanghai

\section{Article history:}

Received: August 26, 2017

Received in revised form:

January 17, 2018

Accepted: March 15, 2018

Available online: December 6, 2018

Copyright 2018 Wan Li, Bindong Sun, Chun Yin, Tinglin Zhang \& Qianqian Liu http://dx.doi.org/10.5198/jtlu.2018.1286

ISSN: 1938-7849 | Licensed under the Creative Commons Attribution - Noncommercial License 4.0

The Journal of Transport and Land Use is the official journal of the World Society for Transport and Land Use (WSTLUR) and is published and sponsored by the University of Minnesota Center for Transportation Studies. 


\section{Introduction}

Urban rail is experiencing a surge in popularity around the world and, with it, an increasing number of studies are assessing the value of rail transit. Most studies, however, have a narrow focus on the effects of rail transit, including the propensity to drive less (Cao \& Cao, 2014; Zhao, 2014; Combs \& Rodríguez, 2014; Huang, Cao, Yin, \& Cao, 2017; Zhang, Zheng, Sun, \& Wang, 2017), the mitigating effect on traffic congestion (Baum-Snow \& Kahn, 2005; Anderson, 2014), the reduction in environmental pollution (Chen \& Whalley, 2012; Goel \& Gupta, 2015), and the growth effect on land/property values (Bowes \& Ihlanfeldt, 2001; Debrezion, Pels, \& Rietveld, 2007; Martínez \& Viegas, 2012; Mohammad, Graham, Melo, \& Anderson, 2013; Cao \& Lou, 2017). All of the above studies just provide objective cost-benefit analyses rather than subjective evaluations, which is an empirical deficit in assessing the benefits of rail transit (De Vos, Mokhtarian, Schwanen, van Acker, \& Witlox, 2013; Reardon \& Abdallah, 2013; Wu, 2014). Assessing rail transit with regards to perceived satisfaction is a significant supplementary source of evidence to the traditional and objective cost-benefit evaluation. We recognize that satisfaction and well-being may strictly different from happiness, but we will use the terms interchangeably in this paper. As it may also directly affect individuals' decision on whether or not use metro rail, this kind of subjective evaluation has the potential to influence the future development of rail transit.

This paper aims to provide a quantitative assessment of the benefits of metro proximity, one of the most valued attributes of public transit, to individuals' happiness. The central empirical challenge is selfselection, or the sorting effect (De Vos et al., 2013; Wang \& Lin, 2014). To the degree that residential location is the result of personal preferences for metro, living around a subway station can increase happiness. To overcome this issue, we take advantage of the rapid expansion of the metro rail transit system in Shanghai and the unique urban housing market in China. This study identifies two subsamplesurban households that were purchased their house 10 years earlier than the operation of their nearest metro station, and households in the non-market housing (chai-qian an-zhi fang) whose locations are predetermined - to provide a robust and relatively exogenous estimation of urban rail transit's effect on happiness.

This study contributes to the literature in at least three important ways. First, it adds to the literature on assessment of urban rail from the subjective view. Though scholars are increasingly evaluating rail transit benefits, there has been a surprisingly little study of how metro proximity contributes to happiness. Our work can serve as a useful additional dimension for assessing rail beyond traditional cost-benefit evaluations and offer a new insight in evaluating the urban rail. Second, this paper also fills an empirical gap in the field of happiness economics. Despite the fact that many studies have examined the determinants of happiness, few have focused on travel and even fewer on metro proximity. Third, the paper contributes to existing research by providing robust estimations that deal convincingly with the endogeneity in the residential location. Of the handful of studies on metro proximity and happiness, to the best of our knowledge, only two papers (Wu, 2014, 2015) have addressed the longstanding concern of residential self-selection. In fact these two papers have the same author, and there is no essential difference in method and data between these two papers. Building on Wu $(2014,2015)$ ground-breaking methodology, we carefully tackle the self-selection problem.

The paper is structured as follows. The next section reviews literature relevant to the aim of this study. The third section introduces the specific circumstance of non-market housing (chai-qian an-zhi fang) in China and household survey data. The results are presented and discussed in the fourth section. The final section concludes and delineates future research needs. 


\section{$2 \quad$ Literature review}

Research on how travel is associated with individuals' evaluation of well-being, the broader field within which we situate the relationship between rail and happiness, is still in its infancy (Reardon \& Abdallah, 2013; De Vos et al., 2016). The limited number of existing studies mainly focus on how travel time or travel mode choice affects happiness.

In terms of travel time, most studies found that trip duration tends to affect travel satisfaction negatively (Cao \& Ettema, 2014; Stutzer \& Frey, 2008; Ettema et al., 2011; Ettema, Friman, Gärling, Olsson, \& Fujii, 2012; Choi, Coughlin, \& D'Ambrosio, 2013; Nie \& Sousa-Poza, 2016). In addition, commuters assign a greater negative value to travel time by public transit than that by car (Ettema et al., 2012). More detailed studies using the Diary-based Day Reconstruction Method showed that the morning commute is the least enjoyable part of a person's day, ahead of working or childcare (Kahneman, Krueger, Schkade, Schwarz, \& Stone, 2004).

As for travel mode, the conclusions are mixed. Based on a commuter survey, St-Louis, Manaugh, van Lierop, and El-Geneidy (2014) found that people using active modes of transportation (i.e., pedestrians and cyclists) are significantly more satisfied than drivers, rail, and bus users. Though Morris and Guerra (2015) confirmed bicyclists have the most positive relationship to commuting, their basic conclusion was that the relationship between respondents' mood and their travel modes tends to be weak and often not statistically significant. While Abou-Zeid (2001) and Duarte et al. (2010) found that commuters of metro and train have a higher level of satisfaction compared with car users, Ettema et al. (2011) and Olsson, Gärling, Ettema, Friman, and Fujii (2013) found higher degrees of travel satisfaction among car users than public transit users. It should be noted that persuading or forcing individuals to switch their travel mode is rather difficult (Pedersen, Friman, \& Kristensson, 2011; Abou-Zeid, Witter, Bierlaire, Kaufmann, \& Ben-Akiva, 2012; Abou-Zeid \& Ben-Akiva, 2012).

Few studies have examined the impact of metro proximity on happiness. While Wu $(2014,2015)$ just focused on this topic, other related papers (see, Brereton, Clinch, \& Ferreira, 2008; Morris, 2011; Leyden, Goldberg, \& Michelbach, 2011) only took the proximity of metro as a control variable, i.e., exploring the relationship of the proximity of metro and happiness is not the prime focus of these studies. But even Wu's $(2014,2015)$ two studies, which not only focus on metro proximity and happiness but also accounts for self-selection, have shortcomings. The main flaw is that his analyses use household survey data aggregated at $1 \mathrm{~km}^{2}$ grid-unit.

An aggregate study has important limitations. First, happiness is an exclusive experience with great individual variation, and personal characteristics are generally accepted as one of the most important sets of factors influencing perceived happiness (Frey \& Stutzer, 2000). Therefore, it is of great necessity to control personality or demographic factors to capture individual heterogeneity in the study of happiness. Furthermore, it is questionable to aggregate micro-survey data to a higher spatial unit (Glaeser, Gottlieb, $\& \mathrm{Ziv}, 2016)$. Even though the survey samples were randomly selected, there are no guarantees that they are sufficient to achieve representativeness within the new aggregated unit, as long as the survey is not specially designed for that geographical unit. In other words, aggregated personal well-being or other household characteristics in a non-census micro-survey cannot represent the real conditions of the new aggregated units.

Moreover, the few existing studies provided mixed empirical results. While Morris (2011), Leyden, Goldberg, and Michelbach $(2011)$ and Wu $(2014,2015)$ found proximity to rail transit is positively related with subjective well-being, Brereton, Clinch, and Ferreira (2008) reported an insignificant effect of proximity to rail station on happiness. Happiness with metro proximity can be explained by transport and non-transport-related benefits (Lewis-Workman \& Brod, 1997; Banister \& Thurstain-Goodwin, 
2011). The transport benefits include the reduction in traffic costs, a relatively relaxing commute and an active and healthy lifestyle. In addition to direct transit-related benefits, transit stations themselves are usually not only the transportation hubs but also the local commercial centers, offering a range of commercial and neighborhood services in their vicinity. However, in a perfectly functioning marketplace, all of these values should be capitalized into property values around transit stations (Morris, 2011). That is to say, the net benefits of metro proximity should have been factored into higher prices of nearby land and housing, which may moderate the positive impact of rail transit on happiness. Yet, in reality, households hardly ever have enough market information, sufficient housing supply or sufficiently low moving costs.

Also, it is worth noting that happiness, like other subjective measures, is not without measurement problems. Happiness is most commonly measured by asking respondents, "Taken all together, how satisfied are you with your life as a whole these days" or "All thing considered, would you say that you are very happy, pretty happy, or not too happy?" This self-reported rating of happiness is widely used in micro-surveys, for example, the Behavioral Risk Factor Surveillance System, the General Social Surveys of the United States, the European opinion surveys, the Chinese General Social Survey and so on. An alternative measure, i.e., the composite self-reported rating of happiness, usually provide a systematical evaluation of happiness. For example, the Satisfaction with Life Scale (Diener, Emmons, Larsen, \& Griffin, 1985) included three separable components of subjective well-being, and the Psychological Well-being (Ryff \& Keyes. 1995) identified six possible life domains to evaluate of one's well-being. The former measure has shortcomings because this indicator cannot specifically cover the different aspects of individual life, and the latter one involves more effort in obtaining the measure of happiness. Moreover, a growing amount of strong evidence supports the validity of the former measure (Bowling, 2005; Layard, 2005; Bray \& Gunnell, 2006). This is another reason for going beyond data availability for why we choose the former measure in this paper.

\section{Data and empirical strategy}

Shanghai is the most developed mega-city in China. The population increased from 16 million in 2000 to 23 million in 2015. This has led to a strong increase in the demand for transport services. According to the 5th Comprehensive Travel Survey of Shanghai, there were 15 rail lines $(577.6 \mathrm{~km})$ and 339 stations by the end of 2014. Rail transit has become the most popular mode of public transportation in Shanghai, and the daily traffic volume generated by urban metro passengers has exceeded 7 million, which is higher than the volume of ground public transport in 2014 (Shanghai Institute for UrbanRural Construction and Transportation Development, 2015). Shanghai's network of subway stations is primarily within the outer-ring road (Figure 1). 


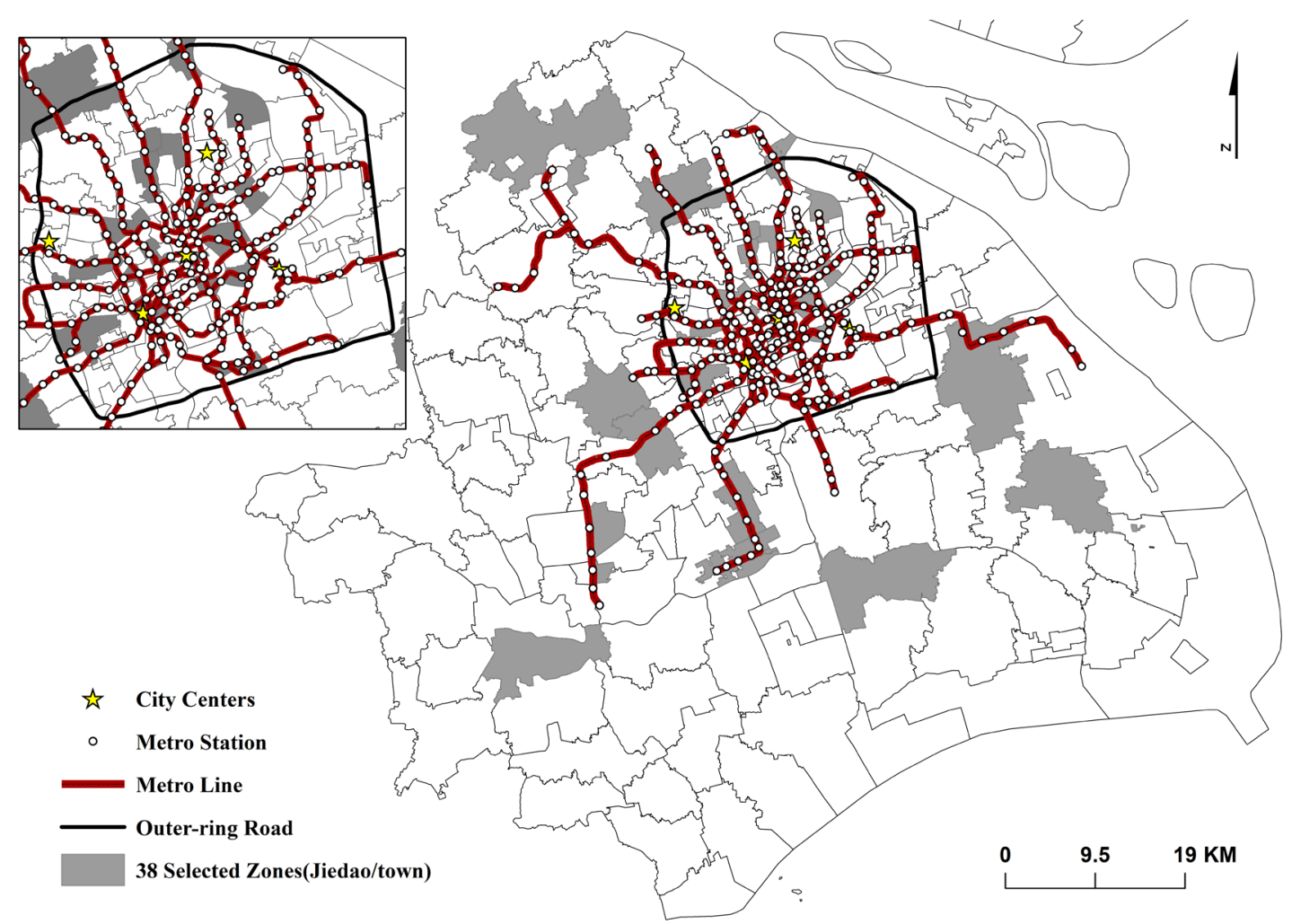

Figure 1: Location of sample and Shanghai metro in 2013

This study uses a unique micro survey dataset of Shanghai in 2013, which tracks people who were born between the years 1980 and 1989. According to the 6th National Population Census in China, about $1 / 3$ of Shanghai's households have at least one family member born during that period. Moreover, respondents, at the time of the survey, were between the ages of 24-33, an age range during which many will be in their greatest transition phase (tertiary education to society, single to marriage). This can place the respondents at a critical juncture, during which they develop work-family commuting habits and decide where to buy or rent a house. But since all our respondents are at a specific age, our findings that come out of this dataset should be interpreted with a certain dose of caution, especially when employed in other specific groups. Also because of this feature of our dataset, we cannot give enough consideration to the specific population groups such as the elderly. This dataset has 2,368 respondents, covering Shanghai's main urbanized areas. Figure 1 shows the spatial distribution of sample units and the extent of the Shanghai metro in 2013.

The principal objective of this paper is to assess the benefits of metro proximity with regards to individuals' happiness. Hence, the focal dependent and independent variables are individual happiness and the proximity of metro stations. The measure of individual happiness, a self-reported rating, is based on responses to the survey statements "I feel happy" (Happ_1) and "I feel life is enjoyable" (Happ_2) on a scale from " 1 - never" to " 4 - always". The proximity of metro (Dis_metro) is defined by the straightline distance from a zone (Jiedao/Town)'s central point to the nearest station. To protect respondent privacy, this survey only provides the information on residential location at the zone (Jiedao/Town) level. The zone is the fundamental administrative organization and census unit in China. The average size of a zone in mainland Shanghai is about $28.84 \mathrm{~km}^{2}$. A higher value of this variable means that the proximity of rail transit is worse. We start with an ordered logit regression for which the empirical model specification can be written as: 


$$
\text { Happ }=\alpha+\beta \cdot \text { Dis_metro }+\theta_{j} \cdot X_{j}+\varepsilon
$$

Where $\beta$ is the coefficients of interest, $X_{j}$ is the vector of all the control variables with parameters $\theta_{j}$, and $\alpha$ and $\varepsilon$ are the constant and error terms respectively.

The selection of control variables $(X)$ is based on previous studies and can be grouped into three categories: built environment variables at the zone level, socio-economic characteristics at the individual/ household level, and a set of variables which may be "bad controls" when included in the model or "missing variables" when excluded. At the zone level, the built environment usually includes five types of variables: density, land-use diversity, design, distance to transit, and destination accessibility (Ewing and Cervero, 2001, 2010). Density, diversity, design and destination accessibility are measured respectively by the density of population, the degree of mixed urban land-use, the road density within the zone, and distance to the nearest of Shanghai's five city centers. Specifically, the population data are for permanent resident population in 2010, which come from the latest census; the degree of mixed urban land-use (Bhat et al., 2000; Zhai et al., 2014) is calculated as:

$$
M I X=1-\frac{\sum_{k=1}^{11}\left|\frac{N_{k}}{N}-\frac{1}{11}\right|}{2}
$$

where $\mathrm{N}_{\mathrm{k}}$ is the number of facility $\mathrm{k}$ in the zone level, $\mathrm{N}$ is the number of total facilities. This paper includes 11 kinds of urban land-use type: government agencies, hospitals, schools and research institutes, hotel and restaurant, company and firm, park, restaurants and entertainment, commercial office, banking, retail, and others; and the basic urban framework of Shanghai is "one main center plus four sub centers." The five centers are People’s Square, Xujiahui Street, Wujiaochang Street, Huamu Streets and Zhenru Street (see Figure 1). Beyond metro proximity, we also add density of bus station as another proxy variable for distance to transit. With the help of ArcGIS 10.1, a professional software package in the field of geographic information systems (GIS), we generate all the zone-level variables. At the individual/household level, this paper considers the most widely used variables that affect individuals' happiness. These variables are personal annual income, gender, age, marital status, years of schooling, health status, number of children, and whether one possesses a Shanghai hukou. It is difficult for residents without a local household registration (the hukou) to benefit from certain services like obtaining vehicle license plates in Shanghai. This paper does not consider the status of respondents' employment, which is highly correlated with the variable personal annual income. We also do not consider the nonlinear effect of age, for our respondents are all within a narrow age range.

We dealt with a set of controversial control variables separately. Variables measured after the variable of interest were determined are generally considered problematic controls, which may give rise to selection bias (Angrist \& Pischke, 2008). Here we face the typical chicken and egg situation. It is difficult to ascertain whether the principal explanatory variable (Dis_metro) or the other control variables (commuting time and car ownership) comes first, therefore there is no easy way to determine the direction of causality. Do residents choose to forego owning a car to afford to be closer to a metro station, or does being close to a metro station enable residents to avoid car ownership? The risk of reverse causality makes these important controls problematic when including it in the model. However, if we excluded these variables from the empirical model, it may become biased due to missing variables, for these variables, in theory, affect our core dependent and independent variables at the same time. To solve this tricky problem, we run different empirical models with or without this set of control variables separately. We outline the definition and statistical information for all variables used in this study in Table 1. 
Table 1: Variable definitions and summary statistics of all the sample

\begin{tabular}{|l|l|l|l|l|l|l|}
\hline Variable & Definition & Obs & Mean & S.D. & Min & Max \\
\hline Happ_1 & $\begin{array}{l}\text { I feel happy (1=never; 2=seldom; 3= sometimes; 4=al- } \\
\text { ways) }\end{array}$ & 1,751 & 3.31 & 0.85 & 1 & 4 \\
\hline Happ_2 & $\begin{array}{l}\text { I feel life is enjoyable (1=never; 2=seldom; 3= some- } \\
\text { times; 4=always) }\end{array}$ & 1,763 & 3.36 & 0.81 & 1 & 4 \\
\hline Dis_metro & Distance to the nearest metro station (Kilometers) & 1,886 & 2.26 & 3.09 & 0.18 & 12.52 \\
\hline Den_bus & Density of bus station (stations per km $\left.{ }^{2}\right)$ & 1,886 & 20.09 & 14.47 & 0.17 & 71.55 \\
\hline Dis_center & Distance to the nearest city centers (kilometers) & 1,886 & 11.25 & 9.98 & 0.06 & 37.78 \\
\hline Den_pop & Density of population (Ten thousand per km $\left.{ }^{2}\right)$ & 1,886 & 1.92 & 1.51 & 0.07 & 5.1 \\
\hline Mix_land & Degree of mixed urban land use & 1,886 & 0.56 & 0.08 & 0.38 & 0.7 \\
\hline Den_road & Density of road (Kilometers per km $\left.{ }^{2}\right)$ & 1,886 & 4.43 & 2.26 & 0.84 & 10.06 \\
\hline Income & Personal annual income (in CNY 1000) & 1,714 & 62.55 & 52.81 & 0 & 300 \\
\hline Male & Gender (1=male; 0=female) & 1,886 & 0.46 & 0.5 & 0 & 1 \\
\hline Age & Age of the respondent (years) & 1,886 & 28.49 & 2.83 & 24 & 33 \\
\hline Married & Marital status (1=married; 0=single) & 1,885 & 0.52 & 0.5 & 0 & 1 \\
\hline Edu_year & Years of schooling (years) & 1,886 & 14.54 & 3.03 & 1 & 20 \\
\hline & Health status (1= poor \& average; 2= good; 3= great & & & & & \\
\hline Health & \& excellent) & 1,882 & 2.59 & 0.69 & 1 & 3 \\
\hline Children & Number of Children & 1,885 & 0.45 & 0.59 & 0 & 5 \\
\hline Shh_hukou & Possess a Shanghai hukou or not $(1=y e s ; 0=n o)$ & 1,886 & 0.74 & 0.44 & 0 & 1 \\
\hline Comm_time & Two-ways commuting time to work (minutes) & 1,468 & 51.05 & 40.37 & 3 & 180 \\
\hline Car & Possess a car or not (1=yes; 0=no) & 1,885 & 0.31 & 0.46 & 0 & 1 \\
\hline
\end{tabular}

A key empirical challenge in measuring the effects of rail transit infrastructure on happiness is self-selection, a common concern in the field of transportation research. There are at least two potential explanations for the relationship between metro proximity and happiness. On the one hand, metro proximity, as expected, can truly promote individuals' happiness for its transport and non-transportrelated benefits. On the other hand, residential location is the result of the personal preference for metro, whereby living close to the metro station enhances residents' happiness/satisfaction. The latter situation is also known as self-selection: people choose where to live based on their travel needs and preferences (Mokhtarian \& Cao, 2008).

Our solution to this problem is to use the heterogeneity of the sample and choose only the households without the potential self-selection effect. We identify two subsamples that can meet this requirement. The first subsample (Subsample_1) is made up of urban households that bought their house 10 years earlier than the operation of the nearest metro station. We choose this time frame because the construction of a new line of rail transit, from planning to the official operation, will take approximately 8-10 years in China (http://www.ditiezu.com/thread-214663-1-1.html). Therefore, it is fair to say that households meeting that criterion has no strong preference for metro and do not choose their residence based on the presence of a station.

The second subsample (Subsample_2) is made up of households in the non-market housing (chaiqian an-zhi fang). The former houses in this group often were obstacles to the construction of roads and other public facilities and were thus forcibly demolished by the government, leading to the relocation of households into chai-qian an-zhi fang as compensation from the government. The locations of these resettlement properties are usually determined through a complicated and ad-hoc planning process. The households that were relocated had little control over the location of their new residence. See Chen and Han (2014) for a detailed survey of the urban housing market in China. 
In fact, these above two subsamples are two different trains of thought to solve the troubling selfselection problem. Subsample_1 can solve this problem, because residents who move in before the opening of the nearest subway station have no strong preference for metro, and do not choose their residence based on the presence of a station; Subsample_2 can solve the self-selection problem, because the locations of chai-qian an-zhi fang are mainly predetermined by the local government rather than the preference of respondents. The one thing that Subsample_1 and Subsample_2 have in common is residents cannot, to a great extent, choose the location of their housing out of their preference for metro proximity. Descriptive statistics of the subsamples are provided in Table 2.

Table 2: Summary statistics of subsamples

\begin{tabular}{|c|c|c|c|c|c|c|c|c|}
\hline & Mean & S.D. & Min & Max & Mean & S.D. & Min & Max \\
\hline Variable & \multicolumn{4}{|c|}{ Subsample_1 } & \multicolumn{4}{|c|}{ Subsample_2 } \\
\hline Happ_1 & 3.36 & 0.82 & 1 & 4 & 3.25 & 0.92 & 1 & 4 \\
\hline Happ_2 & 3.37 & 0.81 & 1 & 4 & 3.28 & 0.88 & 1 & 4 \\
\hline Dis_metro & 1.41 & 2.26 & 0.18 & 12.52 & 1.21 & 1.73 & 0.26 & 12.52 \\
\hline Den_bus & 21.88 & 12.28 & 0.17 & 71.55 & 21.89 & 11.88 & 0.33 & 44.13 \\
\hline Dis_center & 8.31 & 6.92 & 0.79 & 37.78 & 7.74 & 5.81 & 0.06 & 27.94 \\
\hline Den_pop & 2.14 & 1.15 & 0.07 & 5.10 & 2.03 & 1.22 & 0.15 & 5.01 \\
\hline Mix_land & 0.58 & 0.06 & 0.43 & 0.70 & 0.55 & 0.07 & 0.38 & 0.70 \\
\hline Den_road & 4.36 & 1.68 & 0.84 & 10.06 & 4.29 & 1.54 & 0.84 & 8.78 \\
\hline Income & 61.75 & 52.37 & 0 & 300 & 56.37 & 44.27 & 0 & 300 \\
\hline Male & 0.46 & 0.50 & 0 & 1 & 0.52 & 0.50 & 0 & 1 \\
\hline Age & 28.22 & 2.93 & 24 & 33 & 28.20 & 2.82 & 24 & 33 \\
\hline Married & 0.38 & 0.49 & 0 & 1 & 0.39 & 0.49 & 0 & 1 \\
\hline Edu_year & 15.48 & 2.28 & 1 & 20 & 14.98 & 2.12 & 9 & 20 \\
\hline Health & 2.53 & 0.72 & 1 & 3 & 2.61 & 0.68 & 1 & 3 \\
\hline Children & 0.32 & 0.57 & 0 & 5 & 0.29 & 0.47 & 0 & 2 \\
\hline Shh_hukou & 0.91 & 0.28 & 0 & 1 & 0.94 & 0.24 & 0 & 1 \\
\hline Comm_time & 65.33 & 41.25 & 3 & 180 & 60.48 & 44.59 & 3 & 180 \\
\hline Car & 0.32 & 0.47 & 0 & 1 & 0.24 & 0.43 & 0 & 1 \\
\hline
\end{tabular}

Lastly, the nested nature of the data, whereby all respondents are nested within zones, can lead to a bias in standard error estimation. Clustered standard error and the hierarchical linear model are often applied to address this individual spatial dependency, but the latter usually pay more attention to the interaction between different levels, which is not the focus of this paper. Hence, we employ clustered stander error, an efficient and well-established approach supported by numerous studies, to tackle this bias (Okulicz-Kozaryn \& Mazelis, 2016; Sallis et al., 2009). Our basic results of hierarchical linear models are consistent with clustered standard error.

\section{$4 \quad$ Results}

\subsection{Baseline estimates}

Table 3 reports the ordinal logit estimation results of metro proximity on happiness using the full sample. Columns (1) and (4) consider only the effect of the built environment at the zone level, including the key variable, metro proximity (Dis_metro), while columns (2) and (5) add the common socioeconomic control variables at the individual/household level. In addition, columns (3) and (6) include the set of problematic control variables to alleviate the potential omitted variable problem. These differ- 
ent specifications provide greater robustness in interpreting results and clarify our understanding of the role of metro proximity. All of the columns report the standard errors clustered at a larger geographical level (i.e., district), which is one level above the administrative hierarchy from the zone, to correct for potential inter-group correlation.

Table 3: Ordinal logit regression with full sample

\begin{tabular}{|c|c|c|c|c|c|c|}
\hline & (1) & (2) & (3) & (4) & (5) & (6) \\
\hline & \multicolumn{3}{|c|}{ Happ_1 } & \multicolumn{3}{|c|}{ Happ_2 } \\
\hline Dis_metro & $\begin{array}{c}-0.064^{* * *} \\
(-3.51)\end{array}$ & $\begin{array}{c}-0.074^{* * *} \\
(-4.31)\end{array}$ & $\begin{array}{c}-0.073^{* * *} \\
(-4.61)\end{array}$ & $\begin{array}{c}-0.040^{*} \\
(-1.73)\end{array}$ & $\begin{array}{c}-0.052^{* *} \\
(-2.08)\end{array}$ & $\begin{array}{c}-0.051^{*} \\
(-1.84)\end{array}$ \\
\hline Den_bus & $\begin{array}{l}0.015^{*} \\
(1.74)\end{array}$ & $\begin{array}{c}0.018^{* *} \\
(2.16)\end{array}$ & $\begin{array}{l}0.012 \\
(1.48)\end{array}$ & $\begin{array}{l}0.013 \\
(1.42)\end{array}$ & $\begin{array}{l}0.013 \\
(1.32)\end{array}$ & $\begin{array}{l}0.009 \\
(0.88)\end{array}$ \\
\hline Dis_center & $\begin{array}{c}0.032^{* * *} \\
(3.09)\end{array}$ & $\begin{array}{c}0.029^{* * *} \\
(2.86)\end{array}$ & $\begin{array}{c}0.023^{* *} \\
(2.48)\end{array}$ & $\begin{array}{c}0.025^{\text {*** }} \\
(2.69)\end{array}$ & $\begin{array}{c}0.025^{* * *} \\
(2.83)\end{array}$ & $\begin{array}{c}0.018^{* *} \\
(2.05)\end{array}$ \\
\hline Den_pop & $\begin{array}{l}-0.025 \\
(-0.49)\end{array}$ & $\begin{array}{l}0.042 \\
(0.99)\end{array}$ & $\begin{array}{l}0.053 \\
(1.44)\end{array}$ & $\begin{array}{l}-0.053 \\
(-0.94)\end{array}$ & $\begin{array}{l}-0.001 \\
(-0.02)\end{array}$ & $\begin{array}{l}-0.021 \\
(-0.30)\end{array}$ \\
\hline Mix_land & $\begin{array}{l}0.166 \\
(0.12)\end{array}$ & $\begin{array}{l}0.062 \\
(0.05)\end{array}$ & $\begin{array}{l}-0.326 \\
(-0.26)\end{array}$ & $\begin{array}{l}1.237 \\
(1.01)\end{array}$ & $\begin{array}{l}1.175 \\
(1.18)\end{array}$ & $\begin{array}{l}0.932 \\
(1.03)\end{array}$ \\
\hline Den_road & $\begin{array}{l}-0.047 \\
(-0.95)\end{array}$ & $\begin{array}{c}-0.087^{* *} \\
(-2.47)\end{array}$ & $\begin{array}{c}-0.076^{* *} \\
(-2.57)\end{array}$ & $\begin{array}{l}-0.036 \\
(-0.89)\end{array}$ & $\begin{array}{c}-0.058^{*} \\
(-1.68)\end{array}$ & $\begin{array}{l}-0.047 \\
(-1.42)\end{array}$ \\
\hline Income & & $\begin{array}{c}0.003^{* *} \\
(2.17) \\
\end{array}$ & $\begin{array}{l}0.001 \\
(1.24) \\
\end{array}$ & & $\begin{array}{l}0.003^{*} \\
(1.88)\end{array}$ & $\begin{array}{l}0.002 \\
(0.97) \\
\end{array}$ \\
\hline Male & & $\begin{array}{c}-0.601^{* * *} \\
(-8.19)\end{array}$ & $\begin{array}{c}-0.619^{* * *} \\
(-7.72)\end{array}$ & & $\begin{array}{c}-0.538^{* * *} \\
(-5.74)\end{array}$ & $\begin{array}{c}-0.550^{* * *} \\
(-6.35)\end{array}$ \\
\hline Age & & $\begin{array}{c}-0.066^{* * *} \\
(-3.58)\end{array}$ & $\begin{array}{c}-0.062^{* * *} \\
(-2.98)\end{array}$ & & $\begin{array}{c}-0.037^{*} \\
(-1.94)\end{array}$ & $\begin{array}{c}-0.038^{*} \\
(-1.83)\end{array}$ \\
\hline Married & & $\begin{array}{c}0.806^{* * *} \\
(6.20)\end{array}$ & $\begin{array}{c}0.735^{* * *} \\
(6.71)\end{array}$ & & $\begin{array}{c}0.494^{* * *} \\
(3.67)\end{array}$ & $\begin{array}{c}0.369^{* * *} \\
(2.95)\end{array}$ \\
\hline Edu_year & & $\begin{array}{l}0.047^{*} \\
(1.94)\end{array}$ & $\begin{array}{c}0.072^{\text {*** }} \\
(3.07)\end{array}$ & & $\begin{array}{l}0.034 \\
(1.20)\end{array}$ & $\begin{array}{c}0.052^{*} \\
(1.73)\end{array}$ \\
\hline $\begin{array}{l}\text { Health_2 } \\
\text { (good) }\end{array}$ & & $\begin{array}{l}0.258^{*} \\
(1.81)\end{array}$ & $\begin{array}{c}0.312^{* *} \\
(2.05)\end{array}$ & & $\begin{array}{l}0.141 \\
(1.02) \\
\end{array}$ & $\begin{array}{l}0.228 \\
(1.56)\end{array}$ \\
\hline $\begin{array}{l}\text { Health_3 } \\
\text { (great \& excellent) }\end{array}$ & & $\begin{array}{c}0.551^{* * *} \\
(3.19)\end{array}$ & $\begin{array}{c}0.588^{* * *} \\
(3.22)\end{array}$ & & $\begin{array}{c}0.456^{* *} \\
(2.44)\end{array}$ & $\begin{array}{c}0.581^{* * *} \\
(2.94)\end{array}$ \\
\hline Children & & $\begin{array}{l}0.136 \\
(1.60)\end{array}$ & $\begin{array}{l}0.168 \\
(1.37)\end{array}$ & & $\begin{array}{l}0.218^{* *} \\
(2.26)\end{array}$ & $\begin{array}{c}0.305^{* *} \\
(2.01)\end{array}$ \\
\hline Shh_hukou & & $\begin{array}{l}0.052 \\
(0.44)\end{array}$ & $\begin{array}{l}0.098 \\
(0.65)\end{array}$ & & $\begin{array}{l}-0.011 \\
(-0.10)\end{array}$ & $\begin{array}{l}0.019 \\
(0.14)\end{array}$ \\
\hline Comm_time & & & $\begin{array}{l}0.001 \\
(0.83) \\
\end{array}$ & & & $\begin{array}{l}0.002 \\
(1.58) \\
\end{array}$ \\
\hline Car & & & $\begin{array}{l}0.218^{*} \\
(1.72)\end{array}$ & & & $\begin{array}{l}0.212^{*} \\
(1.66)\end{array}$ \\
\hline Observations & 1,751 & 1,590 & 1,370 & 1,763 & 1,602 & 1,382 \\
\hline Mean_VIF & 3.34 & 2.18 & 2.22 & 3.34 & 2.18 & 2.22 \\
\hline LL & -1908 & -1683 & -1442 & -1857 & -1650 & -1412 \\
\hline Pseudo $\mathrm{R}^{2}$ & 0.0047 & 0.0412 & 0.0438 & 0.0041 & 0.0311 & 0.0338 \\
\hline
\end{tabular}


The estimated coefficients of Dis_metro in all six columns are significantly negative as expected, which means that all else being equal, the closer the individual lives to the subway station, the more likely she/he is to be happier. Specifically, happiness is found to rise from $3.9 \%(=100 *[\exp (-0.040)-1])$ to $7.1 \%(=100 *[\exp (-0.074)-1])$ for every $1 \mathrm{~km}$ reduction in distance from the stations. The values 0.040 in columns (4) and 0.074 in columns (2) and (4) stand for the min and max coefficients among all of the ordinal logit regressions. This basic conclusion is consistent with different control variables and different definitions of happiness. After controlling for socio-economic characteristics (see columns 2, 3, 5 and 6), the size of the coefficients remains fairly stable. It suggests that socioeconomic characteristics are necessary to control variables in this study. More importantly, it shows that our concern about "bad controls" or "missing variables" is unwarranted, for the difference between models with or without these controls is quite small.

An interesting finding is that Dis_center is positively (significant and robust to all specifications) related to happiness. Put another way, living in suburbs leads to a happier life in Shanghai. Inner-city life may not be the best residential choice to promote happiness because of congestion, lack of space, environmental pollution, and high housing/land prices, but no evidence has shown there is a counterurbanization trend in contemporary China. Our finding might serve as an indicator of potential suburbanization in China's mega-cities. Furthermore, road density is negatively related to happiness. This means that road is not only a source of convenience but also possibly perceived as an impediment to a sense of security. No robust evidence has been found to support that the built environment variable at the zone level affects individuals' happiness.

The demographic control variables largely perform as expected. All else equal, females are considerably happier than males, younger people within the range are more likely to be happy, and being married and healthy also are robustly associated with much higher levels of happiness. Interpretation of the importance of income is difficult in this model because we control for the variables of education and car ownership at the same time. All of these three variables have a strong positive correlation with each other, and positively, though not strongly, associated with happiness. As for the set of controversial control variables, only owning a car is positively related to happiness. Commute times seem to be insignificant to happiness.

\subsection{Residential self-selection}

Although the positive effect of metro proximity on happiness is observed after controlling for a series of variables, there is still a chance that this finding due to self-selection. In this part, we use the subsamples to eliminate, or if not, limit the self-selection effect. Panel A in Table 4 is the first subsample, which contains only urban households that bought their house 10 years earlier than the operation of the nearest metro station, and Panel B is based on the subsample of households who live in chai-qian an-zhi fang. 
Table 4: Ordinal logit regression of subsample

\begin{tabular}{|l|c|c|c|c|}
\hline \multirow{2}{*}{} & $(1)$ & $(2)$ & $(3)$ & $(4)$ \\
\cline { 2 - 5 } & \multicolumn{3}{|c|}{ Happ_1 } & \multicolumn{2}{c|}{ Happ_2 } \\
\hline Panel A: Subsample_1 & $\begin{array}{c}-0.181^{* *} \\
(-2.22)\end{array}$ & $\begin{array}{c}-0.172^{* *} \\
(-2.02)\end{array}$ & $\begin{array}{c}-0.219^{* *} \\
(-2.13)\end{array}$ & $\begin{array}{c}-0.196^{* *} \\
(-2.06)\end{array}$ \\
\hline Dis_metro & YES & YES & YES & YES \\
\hline Control Variables_1 & - & YES & - & YES \\
\hline Control Variables_2 & 161 & 160 & 164 & 163 \\
\hline Observations & -156.1 & -154.4 & -155.3 & -151.1 \\
\hline LL & 0.074 & 0.081 & 0.097 & 0.118 \\
\hline Pseudo R & \multicolumn{5}{|c|}{} \\
\hline Panel B: Subsample_2 & $-0.123^{*}$ & $-0.165^{* * *}$ & -0.063 & $-0.111^{* *}$ \\
\hline Dis_metro & $(-1.69)$ & $(-2.76)$ & $(-0.93)$ & $(-2.03)$ \\
\hline Control Variables_1 & YES & YES & YES & YES \\
\hline Control Variables_2 & - & YES & - & YES \\
\hline Observations & 147 & 147 & 148 & 148 \\
\hline LL & -148.8 & -145.1 & -145.8 & -140.9 \\
\hline Pseudo R & 0.084 & 0.106 & 0.094 & 0.125 \\
\hline
\end{tabular}

Control variables_1 refers to all of the control variables in columns 2 or 5 at Table 3, while Control variables_2 refers to Comm_time and Car. Standard errors adjusted in parentheses.

\section{Conclusions}

Though an increasing number of studies are evaluating rail transit benefits, surprisingly few studies focus on how urban metro proximity contributes to disaggregated happiness. Our work serves as a significant supplementary source of evidence to the traditional and objective cost-benefit evaluation and fills the empirical gap on the determinants of happiness from the perspective of the transit-oriented built environment. By identifying two subsamples, we also address the important empirical challenge, the self-selection problem, in measuring the effects of rail transit infrastructure on happiness. In short, using a household survey of Shanghai residents in 2013, we find proximity to a subway station does robustly promote personal happiness.

Our finding yields important insights. First, the government should recognize that encouraging the development of rail transit could be an important way to improve residents' happiness. The potential benefits of proximity to a metro station might be the access to a larger pool of potential services and jobs or the increasing in property values. Second, our findings provide new evidence for transit-oriented development (TOD). As a tool for promoting smart growth, TOD can fully take advantage of the benefit of metro transit and increase individuals' happiness. Moreover, China has seen rapid growth in the sharing economy since 2015, especially in the field of transportation. Shared bike programs, such as ofo and mobike, have increased the proximity of metro stations by connecting the first/last mile to the origin/ destination. This gives prominence to the study of urban rail proximity in the future.

Four limitations are worth mentioning for future research. First, our results need to be interpreted with caution. Although we took much care to address the long-term concern for self-selection, we cannot guarantee a consistent result when including alternatives into consideration. For example, we cannot be sure whether residents will be happier if the government transfer the rail transit fund to personal transportation allowances. Also since all our respondents are at a specific age, it requires more serious 
consideration before employing our finding in other specific groups. Moreover, although we justified our choice to use a self-reported rating of happiness, further research is needed to focus on the composite rating, which can provide a systematic evaluation of happiness. Further research should also provide more direct empirical evidence on why metro proximity can promote happiness.

\section{Acknowledgements}

We thank the financial support from National Natural Science Foundation of China (41471139), Major Program of National Social Science Foundation of China (17ZDA068), the MOE Project of Key Research Institute of Humanities and Social Sciences at Universities (16JJD790012), and the affiliated institutions of the first four authors - The Center for Modern Chinese City Studies, Future City Lab, School of Urban and Regional Science, and East China Normal University. The corresponding author of this work is Bindong Sun. 


\section{References}

Abou-Zeid, M. (2001). Measuring and modeling activity and travel well-being. Master's thesis, Massachusetts Institute of Technology, Cambridge, MA. Retrieved from https://dspace.mit.edu/handle/1721.1/55151

Abou-Zeid, M., \& Ben-Akiva, M. (2012). Travel mode switching: Comparison of findings from two public transportation experiments. Transport Policy, 24, 48-59.

Abou-Zeid, M., Witter, R., Bierlaire, M., Kaufmann, V., \& Ben-Akiva, M. (2012). Happiness and travel mode switching: Findings from a Swiss public transportation experiment. Transport Policy, 19, 93-104.

Anderson, M. L. (2014). Subways, strikes, and slowdowns: The impacts of public transit on traffic congestion. The American Economic Review, 104, 2763-2796.

Angrist, J. D., \& Pischke, J. S. (2008). Mostly harmless econometrics: An empiricist's companion. Princeton, NJ: Princeton University Press.

Banister, D., \& Thurstain-Goodwin, M. (2011). Quantification of the non-transport benefits resulting from rail investment. Journal of Transport Geography, 19, 212-223.

Baum-Snow, N., \& Kahn, M. E. (2005). Effects of urban rail transit expansions: Evidence from sixteen cities, 1970-2000. Brookings-Wharton Papers on Urban Affairs, 147-206.

Bhat, C., Handy, S., Kockelman, K., Mahmassani, H., Chen, Q., \& Weston, L. (2000). Urban accessibility index: Cumulative opportunities. Research report. Retrieved from http://ctr.utexas.edu/wpcontent/uploads/pubs/4938_1.pdf

Bowes, D. R., \& Ihlanfeldt, K. R. (2001). Identifying the impacts of rail transit stations on residential property values. Journal of Urban Economics, 50, 1-25.

Bowling, A. (2005). Measuring health: A review of quality of life measurement scales. New York: Open University Press.

Bray, I., \& Gunnell, D. (2006). Suicide rates, life satisfaction and happiness as markers for population mental health. Social Psychiatry and Psychiatric Epidemiology, 41, 333-337.

Brereton, F., Clinch, J. P., \& Ferreira, S. (2008). Happiness, geography and the environment. Ecological Economics, 65, 386-396.

Cao, J., \& Cao, X. (2014). The impacts of LRT, neighborhood characteristics, and self-selection on auto ownership: Evidence from Minneapolis-St. Paul. Urban Studies, 51, 2068-2087.

Cao, X. J., \& Ettema, D. F. (2014). Satisfaction with travel and residential self-selection: How do preferences moderate the impact of the Hiawatha Light Rail Transit line? Journal of Transport and Land Use, 7, 93-108.

Cao, X., \& Lou, S. (2017). When and how much did the Green Line LRT increase single-family housing values in St. Paul, Minnesota? Journal of Planning Education and Research, forthcoming.

Chen, Y., \& Whalley, A. (2012). Green infrastructure: The effects of urban rail transit on air quality. American Economic Journal: Economic Policy, 4, 58-97.

Choi, J., Coughlin, J., \& D'Ambrosio, L. (2013). Travel time and subjective well-being. Transportation Research Record: Journal of the Transportation Research Board, 2357, 100-108.

Combs, T. S., \& Rodríguez, D. A. (2014). Joint impacts of bus rapid transit and urban form on vehicle ownership: New evidence from a quasi-longitudinal analysis in Bogotá, Colombia. Transportation Research Part A: Policy and Practice, 69, 272-285.

De Vos, J., Mokhtarian, P. L., Schwanen, T., van Acker, V., \& Witlox, F. (2016). Travel mode choice and travel satisfaction: Bridging the gap between decision utility and experienced utility. Transportation, 43, 771-796. 
De Vos, J., Schwanen, T., van Acker, V., \& Witlox, F. (2013). Travel and subjective well-being: A focus on findings, methods and future research needs. Transport Reviews, 33, 421-442.

Debrezion, G., Pels, E., \& Rietveld, P. (2007). The impact of railway stations on residential and commercial property value: A meta-analysis. The Journal of Real Estate Finance and Economics, 35, 161-180.

Diener, E., Emmons, R. A., Larsen, R. J., \& Griffin, S. (1985). The satisfaction with life scale. Journal of Personality Assessment, 49, 71-75.

Duarte, A., Garcia, C., Giannarakis, G., Limáo, S., Polydoropoulou, A., \& Litinas, N. (2010). New approaches in transportation planning: Happiness and transport economics. Netnomics, 11, 5-32.

Ettema, D., Friman, M., Gärling, T., Olsson, L. E., \& Fujii, S. (2012). How in-vehicle activities affect work commuters' satisfaction with public transport. Journal of Transport Geography, 24, 215-222.

Ettema, D., Gärling, T., Eriksson, L., Friman, M., Olsson, L. E., \& Fujii, S. (2011). Satisfaction with travel and subjective well-being: Development and test of a measurement tool. Transportation Research Part F: Traffic Psychology and Behavior, 14, 167-175.

Ewing, R., \& Cervero, R. (2001). Travel and the built environment: A synthesis. Transportation Research Record: Journal of the Transportation Research Board, 1780, 87-114.

Ewing, R., \& Cervero, R. (2010). Travel and the built environment: A meta-analysis. Journal of the American Planning Association, 76, 265-294.

Frey, B. S., \& Stutzer, A. (2000). Happiness, economy and institutions. The Economic Journal,110, 918-938.

Glaeser, E. L., Gottlieb, J. D., \& Ziv, O. (2016). Unhappy cities. Journal of Labor Economics, 34, 129 182.

Goel, D., \& Gupta, S. (2015). The effect of metro expansions on air pollution in Delhi. The World Bank Economic Review, 31, 271-294.

Huang, X., Cao, X. J., Yin, J., \& Cao, X. (2017). Effects of metro transit on the ownership of mobility instruments in Xi'an, China. Transportation Research Part D: Transport and Environment, 52, 495-505.

Kahneman, D., Krueger, A. B., Schkade, D. A., Schwarz, N., \& Stone, A. A. (2004). A survey method for characterizing daily life experience: The day reconstruction method. Science, 306, 1776-1780.

Layard R. (2005). Happiness: Lessons from a new science. London: Penguin Books.

Lewis-Workman, S., \& Brod, D. (1997). Measuring the neighborhood benefits of rail transit accessibility. Transportation Research Record: Journal of the Transportation Research Board, 1576, 147-153.

Leyden, K. M., Goldberg, A., \& Michelbach, P. (2011). Understanding the pursuit of happiness in ten major cities. Urban Affairs Review, 47, 861-888.

Martínez, L. M. G., \& Viegas, J. M. (2012). The value capture potential of the Lisbon Subway. Journal of Transport and Land Use, 5, 65-82.

Mohammad, S. I., Graham, D. J., Melo, P. C., \& Anderson, R. J. (2013). A meta-analysis of the impact of rail projects on land and property values. Transportation Research Part A: Policy and Practice, 50, 158-170.

Mokhtarian, P. L., \& Cao, X. (2008). Examining the impacts of residential self-selection on travel behavior: A focus on methodologies. Transportation Research Part B: Methodological, 42, 204-228.

Morris, E. A. (2011). Access and outcomes: Transportation, location, and subjective well-being. Doctoral dissertation, University of California, Berkeley, CA. Retrieved from http://uctc-access.net/research/ UCTC-DISS-2011-07.pdf

Morris, E. A., \& Guerra, E. (2015). Are we there yet? Trip duration and mood during travel. Transportation Research Part F: Traffic Psychology and Behavior, 33, 38-47.

Nie, P., \& Sousa-Poza, A. (2016). Commute time and subjective well-being in urban China. China Economic Review, forthcoming. 
Okulicz-Kozaryn, A., \& Mazelis, J. M. (2016). Urbanism and happiness: A test of Wirth's theory of urban life. Urban Studies, forthcoming.

Olsson, L. E., Gärling, T., Ettema, D., Friman, M., \& Fujii, S. (2013). Happiness and satisfaction with work commute. Social Indicators Research, 111, 255-263.

Pedersen, T., Friman, M., \& Kristensson, P. (2011). Affective forecasting: Predicting and experiencing satisfaction with public transportation. Journal of Applied Social Psychology, 41, 1926-1946.

Reardon, L., \& Abdallah, S. (2013). Well-being and transport: Taking stock and looking forward. Transport Reviews, 33, 634-657.

Ryff, C. D., \& Keyes, C. L. M. (1995). The structure of psychological well-being revisited. Journal of Personality and Social Psychology, 69(4), 719-727.

Sallis, J. F., Saelens, B. E., Frank, L. D., Conway, T. L. Slymen, D. J., Cain, K. L., \& Kerr, J. (2009). Neighborhood built environment and income: Examining multiple health outcomes. Social Science \& Medicine, 68,1285-1293.

Shanghai Institute for Urban-Rural Construction and Transportation Development. (2015). Annual report of Shanghai integrated traffic in 2015. Traffic and Transportation, 31, 7-11.

St-Louis, E., Manaugh, K., van Lierop, D., \& El-Geneidy, A. (2014). The happy commuter: A comparison of commuter satisfaction across modes. Transportation Research Part F: Traffic Psychology and Behavior, 26, 160-170.

Stutzer A., \& Frey, B. S. (2008). Stress that doesn't pay: The commuting paradox. The Scandinavian Journal of Economics, 110, 339-366.

Wang, D., \& Lin, T. (2014). Residential self-selection, built environment, and travel behavior in the Chinese context. Journal of Transport and Land Use, 7, 5-14.

Wu, W. (2014). Does public investment improve homeowners' happiness? New evidence based on micro surveys in Beijing. Urban Studies, 51, 75-92.

Wu, W. (2015). Rail access and subjective well-being: Evidence from quality of life surveys. Journal of Comparative Economics, 43, 456-470.

Zhai, B., Mao, Q., Zhang, J., Xie, Y., \& Chen, X. (2014). An empirical study of the factors associated with residents' outdoor activities. Urban Development Studies 21, 54-61. [In Chinese]

Zhang Y. J., Zheng. S. Q, Sun, C., \& Wang, R. (2017). Does subway proximity discourage automobility? Evidence from Beijing. Transportation Research Part D: Transport and Environment, 52, 506-517.

Zhao, P. (2014). The impact of the built environment on bicycle commuting: Evidence from Beijing. Urban Studies, 51,1019-1037. 